\title{
MELIRIK IKAN NILA DALAM SISI EKONOMI KREATIF PADA KOMUNITAS PEMUDA DESA GELAM JAYA KABUPATEN TANGERANG
}

\author{
Sonny Santosa \\ Program Studi Manajemen, Fakultas Bisnis, Universitas Buddhi Dharma \\ snnsantosa@gmail.com
}

\begin{abstract}
This research is motivated by the phenomenon of the Covid-19 Pandemic which has almost hit all nations in the world and has caused a domino effect on the joints of human life itself. Various fields experience tidal effects, including one of them is the economic sector. To deal with uncertain situations and ups and downs like today that can make a country enter the trough of an economic crisis, it is necessary to have support from the central government to the regions to jointly generate the economy. Therefore, this study aims to analyze the factors that influence the interest of the youth community of Gelam Jaya Village to contribute to developing tilapia fish farming which aims to increase the original income of the environment so as to be able to make choices for the community to continue to get income distribution. The problem in this research is the low interest of the youth community to take part in creative economic efforts for the surrounding environment. In this study, a research model was proposed to analyze the interest of young people in actively contributing to tilapia cultivation, where from the location side, Gelam Jaya Village made it possible to develop collaboration with related agencies in terms of generating the creative economy. This study examines the factors that can be obtained when interviewing the village regarding the youth's interest in contributing to the creative economy. This study uses answers from 169 respondents who were sampled. The data analysis tool used is factor analysis in the SPSS v.18 program. The results of data analysis show that the Situational Involvement (XI) factor of 0.766 is one of the most dominating factors for respondents in actively contributing to developing tilapia cultivation in Gelam Jaya Village, and has a value above 0.50.
\end{abstract}

Keywords : Factor Analysis, Creative Economy

\begin{abstract}
ABSTRAK
Penelitian ini dilatarbelakangi dari fenomena mengenai adanya Pandemic covid-19 yang hampir melanda diseluruh bangsa didunia ini dan telah menimbulkan efek domino terhadap sendi kehidupan manusia itu sendiri. Berbagai bidang mengalami efek pasang surut, termasuk salah satu diantaranya adalah bidang ekonomi. Untuk menghadapi situasi yang tidak menentu dan pasang surut seperti saat ini yang mampu membuat sebuah Negara masuk dalam palung krisis ekonomi, maka perlu adanya dukungan dari pemerintah pusat hingga daerah untuk bersama-sama membangkitkan ekonomi. Oleh karena itu penelitian ini bertujuan untuk menganalisis factor-faktor yang mempengaruhi minat komunitas pemuda Desa Gelam Jaya untuk berkontribusi dalam mengembangkan budidaya ikan nila yang bertujuan untuk meningkatkan pendapatan asli lingkungan sehingga mampu membuat pilihan bagi masyarakat untuk tetap mendapatkan pemerataan pendapatan. Permasalahan dalam penelitian ini adalah masih rendahnya minat komunitas pemuda untuk berkiprah dalam usaha ekonomi kreatif bagi lingkungan sekitar. Dalam penelitian ini diajukan model penelitian untuk menganalisis minat para pemuda dalam turut berkontribusi aktif dalam budidaya ikan nila, dimana dari sisi lokasi, Desa Gelam jaya memungkinkan untuk mengembangkan tali kerjasama dengan Dinas terkait dalam hal membangkitkan ekonomi kreatif. Penelitian ini menguji factor-faktor yang sekiranya didapat ketika wawancara dengan pihak Desa terkait minat para pemuda untuk berkontibusi dalam ekonomi kreatif. Penelitian ini menggunakan jawaban dari 169 responden yang dijadikan sampel. Alat analisis data yang digunakan adalah analisis factor pada program SPSS v.18. Hasil analisa data menunjukkan bahwa factor Adanya Situational involvement (X1) sebesar 0,766 merupakan salah satu factor yang paling mendominasi responden dalam turut berkontribusi aktif untuk mengembangkan budidaya ikan nila di Desa Gelam Jaya, dan memiliki nilai diatas 0,50.
\end{abstract}

Kata Kunci: Analisis Faktor, Ekonomi Kreatif

\section{PENDAHULUAN}

Sejak pandemi covid-19, minat masyarakat memelihara ikan jenis air tawar menunjukkan trend yang cukup meningkat, mengingat kini banyak lapisan masyarakat yang bekerja dirumah sehingga memelihara ikan air tawar menjadi hiburan tersendiri. Semakin tingginya minat masyarakat 
membudidaya ikan nila, membuat pemerintah setempat fokus mengembangkan budidaya ikan nila jenis air tawar ini. Jenis ikan nila menjadi salah satu jenis ikan yang paling banyak digemari oleh masyarakat, hal ini seiring dengan langkah Dinas Ketahanan Pangan, Pertanian dan Perikanan Kabupaten Tangerang yang kini telah mengembangkan budidaya ikan, salah satunya dengan mengoptimalkan Pendapatan Asli Daerah (PAL) bersama masyarakat setempat untuk membuat balai benih ikan di Jalan Akses Kutabaru, Desa Gelam Jaya, Kecamatan Pasar Kemis, Kabupaten Tangerang.

Balai benih ikan nila ini berfungsi untuk menghasilkan benih ikan (nila) jenis air tawar seperti ikan nila merah nifi, gift biasa, nila gesit, citralada. Saat ini benih yang paling diunggulkan adalah ikan nila merah nifi dan citralada, dua jenis ikan ini ditargetkan dapat menjadi penambah icon ekonomi yang baru bagi masyarakat Desa Gelam Jaya. Saat ini Pemerintah Desa Gelam Jaya baru merintis salah satu lokasi komplek yang strategis untuk didaulat sebagai cikal bakal komplek "kampung" nila, keberadaan balai ikan ini diharapkan bisa dapat mengangkat potensi perikanan jenis ikan air tawar (nila) sehingga bisa meningkatkan kesejahteraan warga masyarakat Desa Gelam Jaya.

Berdasarkan informasi yang dikumpulkan (Jaya, 2019) bahwa pada kenyataannya Desa Gelam Jaya, Kecamatan Pasar Kemis, Kabupaten Tangerang merupakan hasil dari pemekaran Kelurahan Kuta Jaya, Kecamatan Pasar Kemis, Kabupaten Tangerang, sejak terpisah dari Kelurahan Kuta Jaya, Desa Gelam Jaya telah beberapa kali mengalami pergantian kepemimpinan sebagai Kepala Desa Gelam Jaya. Pentingnya memahami kondisi desa untuk mengetahui keterkaitan perencanaan dengan muatan pendukung dan permasalahan yang ada, memberikan arti penting keputusan pembangunan sebagai langkah mendayagunakan dan penyelesaian masalah di masyarakat.

Desa Gelam Jaya merupakan salah satu dari 5 (lima) desa) di wilayah Kecamatan Pasar Kemis, yang terletak 4 KM dari Kecamatan Pasar Kemis, Desa Gelam Jaya sendiri mempunyai luas wilayah seluas 249 hektar. Iklim Desa Gelam Jaya, sebagaimana desa-desa lain di wilayah Indonesia mempunyai iklim kemarau dan penghujan, sehingga hal tersebut mempunyai pengaruh langsung terhadap pola tanam yang ada di Desa Gelam Jaya Kecamatan Pasar Kemis.

Mata pencaharian penduduk di Desa Gelam Jaya sebagian besar masih berada di sector dagang, hal ini menunjukkan bahwa sector dagang memegang peranan penting dalam bidang ekonomi masyarakat desa. Data menurut mata pencaharian penduduk dapat dilihat pada tabel 1 berikut ini :

\section{Tabel 1. Jumlah Penduduk Menurut Mata} Pencaharian

\begin{tabular}{|c|c|c|c|c|c|}
\hline Tani & $\begin{array}{c}\text { Buruh } \\
\text { Tani }\end{array}$ & $\begin{array}{c}\text { PNS/ TNI/ } \\
\text { Polri }\end{array}$ & Swasta & Dagang & $\begin{array}{c}\text { Lain- } \\
\text { Lain }\end{array}$ \\
\hline- & - & 347 & 938 & 32000 & - \\
\hline
\end{tabular}

Sumber data : RPJMDes 2019

Dilihat dari tabel 1 diatas, dapat disimpulkan bahwa mayoritas mata pencaharan penduduk Desa Gelam jaya bergerak di bidang dagang. Permasalahan yang sering muncul berkaitan dengan mata pencaharian penduduk adalah tidak tersedianya lapangan pekerjaan yang kurang memadai dengan perkembangan penduduk sebagaimana tertuang dalam perencanaan pembangunan daerah Kabupaten Tangerang. Hal lain yang perlu diperhatikan dalam pembangunan desa adalah melakukan usaha perluasan kesempatan kerja dengan melakukan penguatan usaha kecil pemberian 
kredit sebagai modal untuk pengembangan usaha khususnya dibidang perdagangan.

Ekonomi kreatif adalah konsep ekonomi dimana sumber daya utamanya terletak pada informasi dan pengetahuan. Pemuda masa kini yang mudah menjangkau segala informasi melalui internet memiliki peluang besar untuk terlibat dalam ekonomi kreatif bangsa, pertanyaan krusial yang seringkali muncul adalah bagaimana mengolah sumber informasi menjadi sebuah kreatifitas.

Menurut (Supramono, 2019) ekonomi kreatif adalah konsep ekonomi sekarang dimana sumber daya utamanya adalah informasi dan pengetahuan, luasnya pengetahuan informasi dan kreatifitas menjadikan salah satu sumber daya utama dalam ekonomi kreatif yang tidak tergantikan, yang terjamin sustainability-nya dan akan terus terbarukan jika sering digunakan. Para pelaku ekonomi kreatif, mereka mengandalkan kemampuannya untuk terus berinovasi, menggali sumber-sumber baru untuk meningkatkan kualitas produk atau jasa yang dihasilkan. Dimana sumber daya utamanya adalah akal dan pikiran mereka yang akan terus dimiliki oleh para manusia yang akan terus terbarukan, tidak akan ada habisnya, selama masih terus digunakan. Para pemuda saat ini, sesungguhnya mereka memiliki peluang yang cukup besar untuk terlibat didalam ekonomi kreatif, keseharian mereka yang terus terkoneksi dengan internet, membuat informasi ada didalam mata mereka dalam sekejap, oleh karena itu, sangat diperlukan sebuah keterampilan bagaimana mengolah informasi itu menjadi salah satu sumber kreatifitas.

Untuk bisa menjadi salah satu pelaku ekonomi kreatif yang sangat kuat, maka para pemuda jaman sekarang, mereka harus memiliki berbagai kemampuan, salah satunya adalah kemampuan untuk siap berubah, untuk selalu siap berdaptasi dengan perubahan, karena hidup baru akan membawa berbagai macam konsep perubahan, kalau tidak memiliki mental yang kuat, maka mereka akan mudah goyah dengan berbagai peruabahan informasi yang mendatang. Dengan kemampuan para pemuda jaman sekarang untuk menggunakan dan berdekatan dengan internet, maka seharusnya mereka bisa memanfaatkan ini sebagai sebuah peluang, jangan hanya sebagai user atau pembeli (pengguna) yang aktif didalam social media, tetapi memanfaatkan peluang itu semua untuk menggali kreatifitas, salah satunya yaitu dengan membangun konsep digital economy, berbagai macam hal ditawarkan seperti platform jual beli online, kemudian membuat sebuat social media, kemudian membuat serach and engine yang "ala Indonesia" sehingga itu bisa menguatkan karakter Negara kita.

Ketika para pemuda ini melakukan surving dengan internet atau mendapat kemudahan mencari informasi dari sumber manapun maka para pemuda ini diharapkan menjadi kunci untuk membuka pintu wawasan yang luas bagi memperdalam kreatifitasnya. Kalau hal ini terus ditingkatkan, maka para pemuda ini tidak akan kehabisan sumber daya utama untuk terlibat dalam ekonomi kreatif, jika para pemuda memahami bahwa ada peluangpeluang untuk berkreatifitas atau tergabung dalam ekonomi kreatif maka itu akan menjadi pilar yang sangat kuat bagi perekonomian Indonesia, ide-ide yang sangat baru akan membawa warna bagaimana peningkatan pendapatan bangsa melalui bisnis digital, melalui e-commerce, e-business.

Trend Budidaya ikan air tawar (nila) di Indonesia termasuk ekonomi kreatif yang telah menjadi tulang punggung bagi 
perekonomian dalam beberapa tahun terakhir, hal ini dapat dilihat dari jumlah sampel rumah tangga usaha budidaya ikan menurut komoditas strategis unggulan nasional sebagai bentuk kontribusi dari industry ekonomi kreatif terhadap pertumbuhan ekonomi menunjukkan jumlah sampel untuk ikan unggulan nasional ternyata ikan nila menduduki peringkat pertama terbanyak dari sisi sampel sebanyak 19.459 jumlah sampel (Statistik, 2016).

\section{Tabel 2. Jenis Ikan Utama}

\begin{tabular}{|c|c|c|c|c|c|c|c|c|c|c|c|}
\hline \multirow[b]{2}{*}{ No. } & \multirow[b]{2}{*}{$\begin{array}{l}\text { Negara/ } \\
\text { Regions }\end{array}$} & \multicolumn{10}{|c|}{ Jenis Ikan Utama/Type of MainFish } \\
\hline & & $\begin{array}{c}\text { Nila' } \\
\text { Nile } \\
\text { Tilapia }\end{array}$ & $\begin{array}{l}\text { Lelel } \\
\text { Terpedo } \\
\text { shaped } \\
\text { catfish }\end{array}$ & $\begin{array}{c}\text { Masl } \\
\text { Common } \\
\text { carp }\end{array}$ & $\begin{array}{l}\text { Guramil } \\
\text { Gourany }\end{array}$ & $\begin{array}{l}\text { Bandeng/ } \\
\text { Milkfish }\end{array}$ & $\begin{array}{l}\text { Patin/ } \\
\text { Pangas } \\
\text { cafish }\end{array}$ & $\begin{array}{l}\text { Kakapl } \\
\text { Snapper }\end{array}$ & $\begin{array}{l}\text { Kerapu } \\
\text { Sunw/ } \\
\text { Spoted coral } \\
\text { grotuper }\end{array}$ & $\begin{array}{l}\text { Udang/ } \\
\text { Shrimp }\end{array}$ & $\begin{array}{l}\text { Rumput } \\
\text { Laut/ } \\
\text { Seanieed }\end{array}$ \\
\hline (1) & (2) & (3) & (4) & (5) & (6) & (7) & (8) & (9) & $(10)$ & (11) & (12) \\
\hline 1 & Sumatera & 76,01 & 47,37 & 30,07 & 22,05 & 15,82 & 12,37 & 0,12 & 4,38 & 13,66 & 0,41 \\
\hline 2 & Jawa & 141,93 & 161,30 & 37,48 & 74,34 & 55,23 & 4,64 & 0,01 & 0,65 & 13,67 & 4,50 \\
\hline 3 & Bali dan Nusra & 7,50 & 2,19 & 1,62 & 0,43 & 3,84 & 0,03 & 0,01 & 0,15 & 0,19 & 12,9 \\
\hline 4 & Kalimantan & 21,57 & 8,02 & 2,85 & 0,51 & 4,42 & 8,74 & 0,03 & 0,13 & 6,40 & 2,12 \\
\hline 5 & Sulawesi & 10,79 & 3,68 & 15,60 & 0,15 & 31,23 & 0,04 & 0,10 & 0,72 & 5,13 & 37,57 \\
\hline 6 & $\begin{array}{l}\text { Maluku dan } \\
\text { Papua }\end{array}$ & 2,83 & 1,01 & 13,27 & 0,10 & 0,15 & 0,00 & 0,02 & 0,16 & 0,00 & 8,59 \\
\hline & Indonesia & 260,64 & 223,57 & 100,89 & 97,58 & 110,69 & 25,82 & 0,29 & 6,19 & 39,05 & 66,12 \\
\hline
\end{tabular}

Sumber: Angka Nasional Hasil Hasil Pencacahan Lengkap ST 2003 dan 2013 Source: National Figures of Complete Enumeration ST 2003 and 2013

Dari tabel diatas dapat disimpulkan bahawa jenis ikan terbanyak yang dibudidayakan oleh rumah tangga usaha budidaya ikan adalah nila.

Untuk mengetahui harapan masyarakat, sejauh mana faktor stimulan para pemuda yang tergabung dalam komunitas pemuda Desa Gelam Jaya terhadap minat membudidayakan ikan nila maka penelitian ini dilakukan dengan mengambil tema Trend Ikan Nila Dalam Sisi Ekonomi Kreatif pada komunitas pemuda Desa Gelam Jaya Kabupaten Tangerang.

\section{METODOLOGI PENELITIAN}

Dari uraian diatas, maka dalam penelitian ini menggunakan analisa faktor dianggap paling tepat, karena dengan analisa faktor kita bisa melihat faktor-faktor apa sajakah yang paling mendominasi para komunitas pemuda gelam jaya untuk bersama-sama berupaya untuk melakukan kontribusi dibidang ekonomi kreatif guna mendapatkan atau meningkatkan pendapatan asli lingungan desa gelam jaya.

Metode penelitian yang digunakan adalah penelitian kuantitatif deskriptif, dimana dalam mencari jawaban atas faktorfaktor tersebut, peneliti membuat sebuah daftar instrumen dalam bentuk angket yang 
disebar kepada responden yang dijadikan sampel, dan dikarenakan Desa Gelam Jaya memiliki jaringan basis pemuda yang dinamakan komunitas pemuda desa gelam jaya, maka populasi yang ditentukan menggunakan teknik pengambilan sampel secara accidental sample atau aksidental sampling (Dyas, 2012) dimana pengambilan sampel berdasarkan siapa saja yang peneliti temui secara aksidental dimana sampel tersebut memenuhi karakteristik populasi sehingga dipandang cocok sebagai sumber data (Sugiyono, 2006).

Jawaban angket yang didapat kemudian dianalisa menggunakan data-data angka dan dioleh menggunakan SPSS v. 18, sedangkan alat ukur atau skala yang ditentukan didalam angket tersebut menggunakan lima alternative jawaban yaitu Sangat Setuju (5), Setuju (4), Netral (3), Tidak Setuju (2) dan Sangat Tidak Setuju (1).

\section{HASIL DAN PEMBAHASAN}

Menurut (Hair, 2010) analisis faktor dikenal juga sebagai suatu metode yang dapat mereduksi sekumpulan variable-variabel asli (original variable) menjadi beberapa variable baru yang disebut dengan factor dimensi atau biasanya juga disebut dengan laten (konstruk). Analisa factor menghasilkan factor atau dimensi (konstruk) dengan minimum loss of information sehingga dalam analisis factor ini menggunakan ukuran the
Kaiser-Meyer Olkin (KMO) Measure Of Sampling Adequacy (MSA) dimana nilai KMO MSA ini dapat digunakan untuk mengetahui apakah proses analisis factor dapat dilakukan atau tidak (Malhotra \& Birks, 2006), syarat nilai KMO MSA harus diatas 0,5 artinya kalau didapat nilai nya dibawah 0,5 makan proses analisis tidak dapat dilanjutkan. Dari tabel 3, menunjukkan nilai KMO yaitu sebagai berikut :

\section{Tabel 3. Nilai KMO}

KMO and Bartlett's Test

\begin{tabular}{|c|c|}
\hline 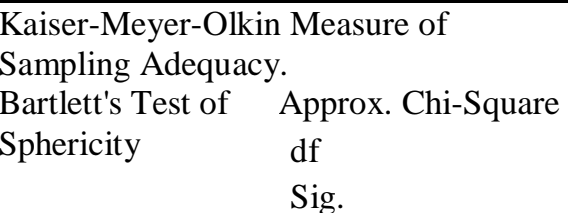 & $\begin{array}{r}167.669 \\
66 \\
.000\end{array}$ \\
\hline
\end{tabular}

Untuk mengetahui kelayakan terhadap suatu variable yang dapat diproses lebih lanjut dalam analisa factor maka peneliti menggunakan tabel output KMO and Bartlett's Test diatas. Pada tabel diatas didapatkan nilai KMO MSA (Kaiser-MeyenOlkin Measure of Sampling Adequacy) 0,706 lebih besar dari 0,50 maka teknik analisis factor dapat dilanjutkan, selain itu, berdasarkan tabel diatas diketahui pula nilai Bartlett's Test of Sphericity (sig.) $(0,000<$ $0,05)$ maka analisis factor dalam penelitian ini dapat dilanjutkan karena sudah memenuhi persyaratan pertama.

Selanjutnya, analisa dilakukan pada hasil tabel 4. Anti image matrices dibawah ini.

\section{Tabel 4. Anti image matrices}

Anti-image Matrices

\begin{tabular}{|c|c|c|c|c|c|c|c|c|c|c|c|c|c|}
\hline & & $\mathrm{X} 1$ & $\mathrm{X} 2$ & $\mathrm{X} 3$ & $\mathrm{X} 4$ & X5 & X6 & $\mathrm{X} 7$ & X8 & X9 & $\mathrm{X} 10$ & X11 & $\mathrm{X} 12$ \\
\hline \multirow{10}{*}{$\begin{array}{l}\text { Anti-image } \\
\text { Covariance }\end{array}$} & $\mathrm{X} 1$ & .681 & .224 & .069 & -.218 & -.075 & -.103 & -.009 & -.054 & -.049 & .029 & .101 & -.016 \\
\hline & $\mathrm{X} 2$ & .224 & .780 & -.012 & .067 & -.080 & .136 & .056 & -.087 & .078 & .036 & .017 & -.122 \\
\hline & X3 & .069 & -.012 & .914 & .035 & .135 & -.130 & -.019 & -.007 & -.096 & .083 & .078 & .059 \\
\hline & $\mathrm{X} 4$ & -.218 & .067 & .035 & .739 & -.177 & -.055 & -.018 & .042 & .023 & -.054 & .008 & -.081 \\
\hline & X5 & -.075 & -.080 & .135 & -.177 & .816 & -.128 & -.012 & .021 & -.104 & -.045 & -.085 & .136 \\
\hline & X6 & -.103 & .136 & -.130 & -.055 & -.128 & .838 & .133 & .012 & .055 & -.017 & .013 & -.063 \\
\hline & $\mathrm{X} 7$ & -.009 & .056 & -.019 & -.018 & -.012 & .133 & .932 & .170 & .033 & -.005 & -.059 & -.077 \\
\hline & X8 & -.054 & -.087 & -.007 & .042 & .021 & .012 & .170 & .944 & .047 & -.018 & .002 & .016 \\
\hline & X9 & -.049 & .078 & -.096 & .023 & -.104 & .055 & .033 & .047 & .911 & .187 & -.030 & -.065 \\
\hline & X10 & .029 & .036 & .083 & -.054 & -.045 & -.017 & -.005 & -.018 & 187 & .892 & .123 & -.125 \\
\hline
\end{tabular}




\begin{tabular}{|ll|r|r|r|r|r|r|r|r|r|r|r|r|}
\hline & X11 & .101 & .017 & .078 & .008 & -.085 & .013 & -.059 & .002 & -.030 & .123 & .927 & .091 \\
& X12 & -.016 & -.122 & .059 & -.081 & .136 & -.063 & -.077 & .016 & -.065 & -.125 & .091 & .912 \\
\hline Anti-image & X1 & $.766^{\mathrm{a}}$ & .307 & .087 & -.308 & -.101 & -.136 & -.012 & -.067 & -.062 & .037 & .128 & -.020 \\
Correlation & $\mathrm{X} 2$ & .307 & $.727^{\mathrm{a}}$ & -.014 & .089 & -.100 & .169 & .065 & -.102 & .092 & .043 & .020 & -.145 \\
& $\mathrm{X} 3$ & .087 & -.014 & $.611^{\mathrm{a}}$ & .043 & .156 & -.148 & -.021 & -.007 & -.105 & .092 & .084 & .064 \\
& $\mathrm{X} 4$ & -.308 & .089 & .043 & $.803^{\mathrm{a}}$ & -.228 & -.070 & -.021 & .051 & .028 & -.067 & .010 & -.099 \\
& $\mathrm{X} 5$ & -.101 & -.100 & .156 & -.228 & $.688^{\mathrm{a}}$ & -.155 & -.014 & .023 & -.120 & -.053 & -.098 & .157 \\
& $\mathrm{X} 6$ & -.136 & .169 & -.148 & -.070 & -.155 & $.751^{\mathrm{a}}$ & .150 & .014 & .062 & -.019 & .015 & -.072 \\
& $\mathrm{X} 7$ & -.012 & .065 & -.021 & -.021 & -.014 & .150 & $.565^{\mathrm{a}}$ & .181 & .035 & -.006 & -.063 & -.083 \\
& $\mathrm{X} 8$ & -.067 & -.102 & -.007 & .051 & .023 & .014 & .181 & $.623^{\mathrm{a}}$ & .051 & -.019 & .002 & .018 \\
& $\mathrm{X} 9$ & -.062 & .092 & -.105 & .028 & -.120 & .062 & .035 & .051 & $.583^{\mathrm{a}}$ & .208 & -.033 & -.071 \\
& $\mathrm{X} 10$ & .037 & .043 & .092 & -.067 & -.053 & -.019 & -.006 & -.019 & .208 & $.657^{\mathrm{a}}$ & .136 & -.139 \\
& $\mathrm{X} 11$ & .128 & .020 & .084 & .010 & -.098 & .015 & -.063 & .002 & -.033 & .136 & $.644^{\mathrm{a}}$ & .099 \\
& $\mathrm{X} 12$ & -.020 & -.145 & .064 & -.099 & .157 & -.072 & -.083 & .018 & -.071 & -.139 & .099 & $.518^{\mathrm{a}}$ \\
\hline
\end{tabular}

a. Measures of Sampling Adequacy(MSA)

Tabel diatas bernama Tabel AntiImage Matrices yang digunakan untuk mengetahui dan menentukan variable mana saja yang layak pakai dalam analisa factor. Kita bisa memperhatikan bagian anti-image correlation, pada tabel tersebut terdapat kode huruf (a) yang artinya tanda untuk measure of sampling adequacy (MSA). Diketahui nilai MSA dari masing-masing yang diteliti adalah sebagai berikut :

1. Situational involvement (X1) sebesar 0,766

2. Inovasi \& Kreatif (X2) sebesar 0,727

3. Memiliki Modal (X3) sebesar 0,611

4. Lingkungan Teknologi (X4) sebesar 0,803

5. Kebebasan Dalam Bekerja (X5) sebesar 0,688
6. Adanya Pendampingan/Pembekalan Rutinitas Untuk Berwirausaha (X6) sebesar 0,751

7. Eksplorasi lingkungan (X7) sebesar 0,565

8. Tantangan Pribadi (X8) sebesar 0,623

9. Keinginan Menjadi Bos (X9) sebesar 0,583

10. Faktor Keuntungan (X10) sebesar 0,657

11. Faktor Demografi (X11) sebesar 0,644

12. Faktor Motivasi (X12) sebesar 0,518

Selanjutnya adalah tabel yang berisi total variance explained menunjukkan nilai masing-masing variabel yang dianalisis, dalam penelitian ini terdapat 12 variabel yang berarti ada 12 komponen yang dianalisis dengan 4 variasi factor yang terbentuk yang bisa dijadikan lanjutan analisa

Total Variance Explained

\begin{tabular}{|r|r|r|r|r|r|r|}
\hline Component & \multicolumn{5}{|c|}{ Initial Eigenvalues } & \multicolumn{3}{c|}{ Extraction Sums of Squared Loadings } \\
\cline { 2 - 7 } & Total & \% of Variance & Cumulative \% & Total & \% of Variance & Cumulative \% \\
\hline 1 & 3.129 & 18.739 & 18.739 & 3.129 & 18.739 & 18.739 \\
3 & 2.434 & 12.949 & 30.687 & 2.434 & 12.949 & 30.687 \\
4 & 2.267 & 11.554 & 41.242 & 2.267 & 11.554 & 41.242 \\
5 & .895 & 11.051 & 51.292 & 2.206 & 11.051 & 51.292 \\
6 & .801 & 7.295 & 57.588 & & & \\
7 & .737 & 6.509 & 65.097 & & & \\
8 & .712 & 5.974 & 72.071 & & & \\
9 & .644 & 5.768 & 78.839 & & & \\
10 & .669 & 5.204 & 85.043 & & & \\
11 & .512 & 5.579 & 90.622 & & & \\
12 & .493 & 4.266 & 95.888 & & & \\
\hline
\end{tabular}

Extraction Method: Principal Component Analysis. 
Empat komponen yang membentuk kelompok dapat kita lihat dari hasil yang ditunjukkan dengan tabel component matrix (dibawah) ini dimana dalam tabel tersebut menunjukkan nilai korelasi atau hubungan antara masing-masing variable dengan factor yang akan terbentuk. Dari output tabel component matrix terlihat bahwa :

1. Sampel responden kelompok pertama terdiri dari variable yang memiliki factor Situational involvement (X1), Lingkungan Teknologi (X4), Kebebasan Dalam Bekerja (X5), Adanya Pendampingan/Pembekalan Rutinitas Untuk Berwirausaha (X6).

2. Sampel responden kelompok kedua terdiri dari variable yang memiliki factor minat wirausaha yang sama yaitu Faktor Keuntungan (X10), Faktor Motivasi (X12)

3. Sampel responden kelompok ketiga terdiri dari variable yang memiliki factor minat wirausaha yang sama yaitu Eksplorasi lingkungan (X7), dan

4. Sampel responden kelompok keempat terdiri dari variable yang memiliki factor minat wirausaha yang sama yaitu Kebebasan Dalam Bekerja (X5), Tantangan Pribadi (X8).

Component Matrix ${ }^{a}$

\begin{tabular}{|l|r|r|r|r|}
\hline & \multicolumn{4}{|c|}{ Component } \\
\cline { 2 - 5 } & \multicolumn{1}{c|}{1} & \multicolumn{1}{c|}{2} & \multicolumn{1}{c|}{3} & \multicolumn{1}{c|}{4} \\
\hline VAR00001 & .764 & -.013 & -.091 & -.071 \\
VAR00004 & .717 & .097 & .110 & .052 \\
VAR00002 & -.599 & .198 & .041 & .254 \\
VAR00006 & .536 & .005 & -.389 & -.074 \\
VAR00005 & .515 & -.169 & .153 & .462 \\
VAR00010 & .168 & .690 & .115 & .068 \\
VAR00009 & .124 & -.557 & -.065 & -.237 \\
VAR00012 & .030 & .500 & .129 & -.362 \\
VAR00011 & -.119 & -.475 & .315 & .404 \\
VAR00007 & .009 & -.049 & .685 & -.351 \\
VAR00008 & -.135 & .182 & -.522 & .409 \\
VAR00003 & -.206 & -.240 & -.440 & -.518 \\
\hline
\end{tabular}

Extraction Method: Principal Component Analysis. a. 4 components extracted.

\section{KESIMPULAN}

Dari hasil diatas setidaknya terdapat empat kelompok sampel dalam keseluruhan populasi yang diukur mengenai factor dominan yang dijadikan factor stimulant ketika minat untuk memulai membangkitkan ekonomi kreatif dari hasil budidaya ikan nila. Hal ini dibuktikan berdasarkan hasil component matrix diatas. Dari hasil tersebut, tampak bahwa factor Adanya Situational involvement (X1) masuk dalam kelompok pertama dan memiliki nilai diatas 0,50. Artinya kelompok yang terbentuk menggambarkan adanya beberapa kesamaan factor dari responden ketika melirik budidaya ikan nila untuk menjadi bagian dari pemerataan pendapatan agar ekonomi kreatif dapat terbentuk.

\section{DAFTAR PUSTAKA}

Afif, L., \& Purbayu, B. S. (2014). FaktorFaktor Yang Mempengaruhi Pendapatan Industri Kreatif Di Indonesia. Diponegoro Journal of Economics, 1.

Bekraft. (2019). Laporan Kinerja Badan Ekonomi Kreatif Tahun 2019. Jakarta: Badan Ekonomi Kreatif.

Burhan. (2013). Mendorong Pertumbuhan Ekonomi Melalui Peningkatan Jumlah Wirausaha : Sebuah Kerangka Penelitian. Bogor: Orange Book FEM IPB.

Dyas, S. (2012). Pengaruh Brand Loyalty Terhadap Variety Seeking. Journal of Social and Industrial Psychology, 43.

Fabian, J. K. (2018, April 05). Jumlah Entrepreneur di Indonesia Jauh di Bawah Negara Maju, Ini Kata Jokowi. Diambil kembali dari https://nasional.kompas.com/: https://nasional.kompas.com/read/201 
8/04/05/17261391/jumlahentrepreneur-di-indonesia-jauh-dibawah-negara-maju-ini-kata-jokowi

Hair. (2010). Multivariate Data Analysis. Jakarta: Salemba Empat.

Jaya, P. D. (2019). RPJMDes. Tangerang: Pemerintah Desa Gelam Jaya.

Malhotra, \& Birks. (2006). Marketing Research. Jakarta: Erlangga.

Statistik, B. P. (2016). Struktur Ongkos Rumah Tangga Usaha Budidaya Ikan. Jakarta: BPS.

Sugiyono. (2006). Statistika untuk penelitian. Bandung: CV. Alfabeta.

Supramono. (2019, Oktober 18). Workshop KIM " Ekonomi Kreatif Di Era Digital “. Diambil kembali dari https://diskominfo.salatiga.go.id: https://diskominfo.salatiga.go.id/work shop-kim-ekonomi-kreatif-di-eradigital/ 